\title{
The Mobilizing Effect of Political Choice
}

\author{
Sara B. Hobolt \& Julian M. Hoerner \\ London School of Economics and Political Science
}

\begin{abstract}
Political choice is central to citizens' participation in elections. Nonetheless, we know little about the individual-level mechanisms that link political choice and turnout. In the paper, we argue that turnout decisions are shaped not only by the differences between the parties (party polarization), but also by the closeness of parties to citizens' own ideological position (congruence), and that congruence matters more in polarized systems where more is at stake. Analyzing crossnational survey data from 80 elections, we find that both polarization and congruence have a mobilizing effect, but that polarization moderates the effect of congruence on turnout. To further explore the causal effect of political choice, we leverage the arrival of a new radical right-wing party in Germany, the Alternative for Germany (AfD), and our findings show that the presence of the AfD had a mobilizing effect, especially for citizens with congruent views.
\end{abstract}

Keywords: Choice, Congruence, Elections, Mobilization, Polarization, Turnout

**Accepted for publication in the European Journal of Political Research** 


\section{Introduction}

Does political choice matter to turnout? Voter participation has declined steadily in recent years across a wide range of advanced democracies (Blais and Rubenson, 2013). At the same time, studies have shown evidence of ideological convergence among parties in Europe, suggesting that parties are offering more limited choice to their electorates (Dorussen and Nanou, 2006; Green and Hobolt, 2008; Evans and De Graaf, 2013; Evans and Tilley, 2017), while democratic theory tends to assume that more choice, and greater political competition, is better for democracy, we lack a nuanced understanding of the effects political choice on turnout. The empirical evidence is mixed. Some scholarship suggests that more choice and greater ideological differences between parties encourage participation (Powell, 1982; Hetherington, 2008; Abramowitz, 2010; Rodon, 2017), whereas other work has argued that polarization demobilizes citizens (Fiorina, Abrams and Pope, 2008; Rogowski, 2014) or has limited effect on turnout (Weisberg and Grofman, 1981; Franklin, 2004).

This raises the question examined in this paper, namely how do different properties of the political choice set matter to individual turnout decisions? Specifically, we focus on two components of choice, polarization and congruence, and how the interaction between them shapes turnout decisions. First, following Downs (1957), we argue that party polarization has a mobilizing effect since the utility of voting is related to the party differential, that is the difference between party platforms. If voters perceive no difference between parties, their utility of voting is low and abstention more likely. In contrast, greater perceived polarization of the parties increases the utility of voting (Downs, 1957; Adams and Merrill, 2003; Franklin, 2004). However, participation in elections is not only related to the differential between parties, but also to the utility - instrumental or expressive - derived from the ability to choose a party that represents a person's ideology or group identity (Rosenstone and Hansen, 1993; Brennan and Hamlin, 1998; Hamlin and Jennings, 2011). In other words, turnout is also shaped by congruence of choice, which denotes the availability of a specific alternative that matches an individual's preferences. While a number of studies have examined the mobilizing effects of polarization and congruence (Powell 1980; Enelow and Hinich, 1984; Kittilson and Anderson, 2011; Lefkofridi, Giger and Gallego, 2014; Rogowski, 2014), we know very little about the interplay between these components of choice on turnout. The major contribution of this paper 
is that it focuses not only on the direct effect of polarization, but examines how greater party political choice moderates the effect of ideological congruence on turnout. Our argument is that congruence has a greater effect on turnout at higher levels of polarization, since more is at stake for voters when parties are very divided. In contrast, when parties offer similar positions (low polarization), the cost of not voting remains relatively constant across levels of congruence, all other things being equal.

We test these arguments in two ways. First, we analyze survey data from the Comparative System of Electoral Systems (CSES) with data from 80 legislative elections held across 27 European countries between 1996 and 2016. The CSES uniquely allows us to examine how variation in perceptions of choice shape turnout decisions in national elections across a wide range of different party systems. In line with our expectations, we find that both polarization and congruence increase the likelihood of turnout, but that congruence is particularly important in more polarized systems. To further isolate the causal impact of a change in the political choice set on turnout, we leverage the arrival of a new German right-wing party, Alternative for Germany (AfD). By comparing regional elections before and after the entrance of the AfD within individual Länder, we show that the presence of this new choice option has a mobilizing effect on citizens, especially those on the far right of the ideological spectrum. The case of the AfD in Germany is particularly suitable for two reasons. First, the historical context of Nazi Germany has mean that a significant space on the right of the political spectrum was not occupied by any parliamentary party in the post-war period. Second, the federal structure of the country and the timing of the regional elections allow us to observe the impact of AfD entry in multiple subnational party systems. We conclude by discussing the implications of these findings for the debate on turnout in general and the mobilizing effect of polarized politics in particular.

\section{Political choice and turnout}

Political choice concerns the ability of voters to choose between candidates or parties with distinct positions on issues that are salient to voters. Such meaningful choice between alternatives are at the heart of what it means to be a democracy and it is seen as crucial to engaging citizens in the democratic process (Schattschneider, 1942; Downs, 1957; Powell, 1982). In most systems, political parties thus play a key role in offering choice to citizens: they organize 
politics and channel societal conflict into institutionalized patterns of political competition in ways that serve to reveal and aggregate voters' preferences such that governments can represent its citizens (see e.g. Dahl, 1971; Pitkin, 1967). The competition between parties in government and opposition parties is crucial in this respect as they provide voters with a viable alternative to those in power (Downs, 1957; Bartolini, 1999). Yet, while it is generally assumed that political choice is a key indicator of the quality of a democratic system (e.g. Dahl, 1956; Dalton, 1985; Lindberg, 2006), we know less about how the properties of the political choices offered to citizens in elections affect their willingness to engage in elections.

The empirical studies that have examined the impact of political choice on turnout generally offer quite mixed evidence. On the one hand, a large body of scholarship has argued that greater ideological conflict increases the stakes associated with election outcomes and therefore increases political participation (see e.g. Downs, 1957; Adams and Merrill, 2003; Franklin, 2004). One of the arguments in favour of proportional representation is that it enhances electoral participation, in part increases the number of parties and thereby the variety of options among which voters can choose (Powell, 1980,1982). There is some evidence in the US context that suggests that greater party polarization leads to increased turnout (Brody and Page 1973; Hetherington, 2008; Brockington, 2009; Abramowitz, 2010; Peress, 2011). On the other hand, studies have found that polarization in a two-party context, such as the US, leaves voters in the center stranded, and thus has a demobilizing effect (Fiorina, Abrams and Pope, 2006; Rogowski, 2014), or no discernable effect (e.g. Weisberg and Grofman, 1981). Comparative evidence on the effect of greater choice on turnout is also mixed. Crepaz (1990) finds a positive and significant effect of party polarization on turnout in 16 democracies, as do Siaroff and Merer (2002) in their analysis of turnout in legislative elections in Europe. In contrast, Franklin's comprehensive study of turnout in 22 advanced democracies finds no effect of polarization (Franklin, 2004) and Blais and Dobrzynska show a negative effect of party system fragmentation on turnout in their large study of 324 elections (Blais and Dobrzynska, 1998). Existing research on polarization and turnout reaches rather conflicting conclusions and often devotes limited attention the individual-level mechanisms that link political choice and turnout (see Blais 2006: 118) ${ }^{1}$

\footnotetext{
${ }^{1}$ One exception is Kittilson and Anderson (2011) who examine how polarization moderates the effect of political efficacy on turnout, arguing that people who feel efficacious are more likely to vote in systems with greater diversity of electoral choice.
} 
To better understand the way in which the properties of political choice may influence political participation, this paper shifts the focus to the individual level. We distinguish between two properties of political choice, namely polarization - the choice between parties and congruence - the choice of a party with matching preferences, and examine the interplay between the two in shaping turnout decisions. Starting with polarization of choice, Schattschneider's notion that "democracy is not to be found in the parties, but between them" (Schattschneider, 1942, 60) encapsulates the idea that it is the ideological difference between parties - or the range of choices offered to citizens - that determines the value that citizens derive from engaging in democracy. This is developed further by Downs who coined the term "expected party differential" to describe the difference in the expected utility between voting for Party A or Party B in a two-party system (Downs, 1957).The greater the party differential, the higher the value a citizen derives from voting for the party closest to her. In contrast, if the parties are very close to each other and some citizens are indifferent among the parties, those "who are indifferent have nothing to gain from voting, so they abstain" (Downs, 1957, 262). This classic utilitarian model has come under much criticism, not least due to the so-called "paradox of voting", which means that for a rational voter, the cost of voting will normally exceed the expected benefits of voting since the likelihood of being a pivotal voter in an election is exceedingly small (Riker and Ordeshook 1968; Fiorina 1990). As a consequence, this simple utilitarian model is unsuccessful in explaining the high levels of voter turnout we normally observe in elections (Blais 2000). Various extensions to the model have been proposed, notably introducing the additional component of "civic duty"; the moral obligation to vote or the expressive utility derived from the act of voting (Riker and Ordeshook 1968). ${ }^{3}$ Even Downs implied that there an additional reason for voting, namely "the advantage of voting per se is that it makes democracy possible" (Downs 1957: 261). Yet, while the simple utilitarian model cannot satisfactorily explain why the high levels of turnout, the idea that voters care about the 'party differential', i.e. the ideological difference between parties, is still useful in helping us understand why some voters are more likely to turn out than others. Indeed, the empirical literature on voting behavior is broadly consistent with the rational choice argument that voters

\footnotetext{
2 According to Downs, it may be rational even for indifferent voters to abstain since voting per se makes democracy possible (Downs, 1957, 261).

${ }^{3}$ Other alternative turnout models include ethical/altruistic preferences for voting, minimax regret, group-based models of voting and adaptive learning models of voting (see Blais 2000 and Geys 2006 for overviews).
} 
are more likely to turn out when more is at stake, e.g. in close elections, suggesting that they care about their ability to influence the outcome of the election (Blais 2000; Feddersen 2004). If people care about the range of choices offered to them, then they are more likely to vote when they perceive greater ideological polarization between parties, since the utility of voting is greater than when parties are ideologically converged. This leads to our polarization hypothesis:

H1: The greater the perceived ideological difference between parties, the greater the likelihood of participating in an election

This discussion of polarization, however, ignores the fact that a greater range and number of choices does not necessarily lead to the availability of a single alternative that matches the preferences of an individual. An individual may be less concerned with the range of choices on offer and more preoccupied with whether there is a single choice that is right for him or her (Lefkofridi, Giger and Gallego, 2014). This leads to the second component of choice, namely congruence, that is the ability to make a choice that matches individual preferences. The importance of congruence is confirmed in both the theoretical and empirical literature on electoral democracy. The spatial voting literature emphasizes that abstention can be due to either indifference (when the party differential is low) or alienation (when the distance to the closest political alternative is high) (Enelow and Hinich, 1984; Adams et al., 2006).

As mentioned above, studies of increasing party polarization in the US have shown that as ideological conflict increases and parties are located further apart in the ideological space, citizens located around the center of the space might decide that neither party appeals enough to them to turn out to vote. These studies suggest that when greater polarization (range of ideological alternatives) leads to the lack of congruent choices for ideologically moderate citizens, turnout is likely to decrease (Fiorina, Abrams and Pope, 2008, 2006; Rogowski, 2014). Indeed, ideological congruence may be important to voters not only from the perspective on an instrumental utility calculation, but because it also concerns the intrinsic value to voters of being able to express a meaningful choice for a party that represents their views, and thereby enter their opinions into the public realm (Przeworski, 2003; Harding, 2011). According to this notion 
of expressive voting, the purpose of the vote is not about the outcome of the election, but the "expression" of identity, values and ideology may be valuable to the individual in its own right and so provide sufficient motivation to vote (Hamlin and Jennings, 2011). Hence, citizens who do not find a party that represents their ideology or identity feel alienated and may therefore decide not to take part in elections (Brody and Page, 1973; Brennan and Hamlin, 1998; Rotemberg, 2009). This leads to our second hypotheses concerning the congruence of choice:

H2: The greater the ideological closeness to a party, the greater the likelihood of participating in an election.

While these arguments about the effect of polarization and congruence have been advanced in the extant literature, we know far less about the interplay between the two in shaping turnout. Will the presence of party that shares your views make you likely to turn out to vote, regardless of the overall electoral supply? Or, is the effect of ideological congruence greater when the parties are further apart? We argue that the impact of congruence on turnout is moderated by the overall nature of the choice set. More specifically, our expectation is that the more polarized a system is seen to be, the greater the effect of congruence on turnout. In a system that is not polarized, the utility cost of not voting should remain relatively constant whether or not there is a congruent choice, since the two parties offer very similar positions. Even for a pivotal voter, the negative consequences of not voting are modest in such a system, given that the distance from the preferred party to a rival party is small in such a system. In contrast, in a highly polarized system, the consequences of abstaining can be much greater for a voter who has a congruent choice, given that rival parties are further ideologically removed from the preferred choice. If there is no congruent choice, the cost of not voting is low even in a highly polarized system, since all alternatives are perceived as equally undesirable. Thus, we expect that ideological proximity considerations will play a greater role in deciding whether or not someone decides to turn out in systems that are more polarized. This leads us to our third hypothesis concerning the moderating effect of party polarization:

H3: The more polarized the party system is perceived to be, the greater the effect of congruence on the likelihood of participating in an election.

The data and operationalization will be discussed in greater detail in the ensuing section. 


\section{Data and Method}

To test the impact of the different components of choice on turnout, we adopt a two-pronged approach. First, we use the Comparative Study of Electoral Systems (CSES) that combines postelectoral surveys from democracies across the world to examine the effect of political choice in a cross-national multi-level analysis. Second, to address some of the potential endogeneity problems in an analysis of observational survey data, we leverage the entry of a new party in Germany, the AfD, to examine the mobilizing effect of the party on the far right by comparing self-reported turnout within regions before and after this new choice options became available.

The CSES is an ideal starting point for our empirical investigation, as it allows us to measure our dependent and independent variables at the individual level in a range of different contexts. CSES respondents are asked to indicate whether they have cast a ballot in the most recent election in their country. They are also asked to place themselves and up to nine political parties on the left-right ideological spectrum on a scale from 1 to 10 . The dataset thus enables us to operationalize both components of electoral choice in an appropriate and cross-nationally comparable way which further allows us to examine the choice-turnout linkage in various electoral contexts with different choice sets, both across countries and over time. To ensure comparability across the countries we are investigating, our analysis just focuses on the European countries in the CSES; that is 80 legislative elections in 27 European countries between 1996 and 2016. Turnout is operationalized as a dummy variable, which takes the value of 1 if the respondent voted and 0 if she abstained. If a respondent could not remember which party she voted for, but reported casting a ballot, and vice versa, we count these respondents as having casted a ballot. ${ }^{4}$

As mentioned above, our approach distinguishes between two properties of political choice: polarization and congruence. The literature proposes numerous different operationalizations of party polarization, all with their different strengths and weaknesses under certain conditions (Dalton, 2008). In our study, we operationalize polarization as the standard deviation of the party placements at the individual level by a respondent on the leftright dimension. For example, if a respondent places party A at 3 and party B at 7 and party $\mathrm{C}$

\footnotetext{
${ }^{4}$ A detailed overview of all operationalizations and original survey questions can be found in the Supplemental Information (SI), Section A, Table SI1.
} 
at 9 , the standard deviation would be 3.06. We thus follow (Sartori, 1976) in focusing on party polarization rather than party fragmentation since we believe that the ideological breadth of choice is more meaningful for a voter than the mere number of choice options. We do, however, include the effective number of electoral parties (ENEP) as a control variable, as this is often used as a measure of party system choice (e.g. Blais and Dobrzynska, 1998; Blais and Rubenson, 2013), and it has no significant effect on turnout in our analysis. Moreover, our results hold for a number of alternative operationalizations of polarization shown in the Supplemental Information.

The second component of choice is the congruence of a respondent's position with the position of a party. Following the classic approach in proximity models of voting, we focus on ideological closeness on the dominant dimension of contestation in Europe, namely the leftright dimension (McDonald and Budge, 2005; Mair, 2008). We thus operationalize congruence as the distance of the respondent to the party closest to her in spatial terms. In order to identify the closest party, we calculate the distance from the respondents' self-placements to each party they place on the left-right spectrum and then identify the smallest absolute distance. We use the negative of this distance to construct the congruence variable. Moreover, we include an interaction term between the polarization measure and the congruence measure, as we are interested in the effect of congruence on turnout at different levels of perceived party system polarization. It is worth mentioning that there is only a very weak (and negative) correlation of -0.08 between congruence and polarization.

One potential criticism of the operationalization is that we rely on the left-right selfplacements of voters and their party placements to assess polarization and congruence. Arguably, this reliance on voters' subjective perceptions raises the possibility of projection effects where voters locate political alternatives they do not like further away from their position and bring closer those parties with which they sympathize (Krosnick, 1990). While we cannot rule out the possibility of projection, we believe that it is nonetheless appropriate to focus on voters' perceptions since it is precisely these perceptions of the political reality that inform the decision to vote. This is analogous to relying on subjective perceptions of the economy when analyzing economic voting, as it is precisely the political landscape as perceived by the voter which we should be interested in. Stevenson and Duch $(2013,320)$, for example, argue that "the 'observed economy' for any individual is best thought of as some aggregation of an 
idiosyncratic sample of economic messages from the distribution of all such economic messages that are available in some interval of time in some jurisdiction". A similar argument could be made in our case: perceived congruence and polarization is the choice range which the voter constructs based on the message available to her at election time. Hence, it is this perceived set of choices which we should be interested in rather than an (only seemingly objective) choice set identified by expert surveys or the aggregation of individual voters' perceptions. Furthermore, to get a better handle on the causal effect of choice on turnout, we also analyze a specific case, the rise of the AfD in Germany, which allows us to test the effect of an exogenous change in the available choice on turnout decisions. This is discussed in greater detail below.

We also consider the role of institutions on turnout, since electoral systems unsurprisingly have been shown to matter to participation. Firstly, we control for the effect of the electoral system more broadly defined. Thus, we include a dummy for majoritarian electoral systems. This allows us to assess whether the particularities of these systems influence how polarization and congruence affect turnout. We also control for compulsory voting rules. As mentioned above, we also include the effective number of electoral parties (ENEP) in our models in order to take into account the fragmentation of a party system (Laakso and Tagepera 1979) and to explore whether the hypothesized effect of ideological polarization holds even when controlling for the number of parties.

At the individual level, we control for a number of socio-demographic characteristics that have been shown to be correlated with turnout, namely income, education, political knowledge and gender. We use multiple imputation to deal with missing data. To account for the structure of the dataset, we fit multilevel logistic regression models with random intercepts at the level of country-elections. Descriptive Statistics can be found in the Supplemental Information (See SI Section B, Table SI2).

\section{Results from the cross-national study}

As shown below, our results from the analysis of CSES data provide empirical support for our hypotheses that both properties of political choice - polarization and congruence play an important role in determining the extent to which citizens are likely of actively participate in the democratic process by casting a ballot. 
Table 1: The effects of polarization and congruence on turnout

\begin{tabular}{lll}
\hline \hline & Model 1 & Model 2 \\
\hline Polarization & $\mathbf{0 . 1 8}$ & $\mathbf{0 . 2 2}$ \\
& $(0.01)$ & $(0.01)$ \\
Congruence & $\mathbf{0 . 1 2}$ & -0.01 \\
& $(0.01)$ & $(0.02)$ \\
Polarization x Congruence & & $\mathbf{0 . 0 5}$ \\
& & $(0.01)$ \\
Age & $\mathbf{0 . 3 3}$ & $\mathbf{0 . 3 3}$ \\
& $(0.01)$ & $(0.01)$ \\
Gender & $\mathbf{0 . 0 4}$ & $\mathbf{0 . 0 4}$ \\
& $(0.02)$ & $(0.02)$ \\
Education & $\mathbf{0 . 1 3}$ & $\mathbf{0 . 1 3}$ \\
& $(0.01)$ & $(0.01)$ \\
Income & $\mathbf{0 . 1 1}$ & $\mathbf{0 . 1 1}$ \\
& $(0.01)$ & $(0.01)$ \\
Political Knowledge & $\mathbf{0 . 3 9}$ & $\mathbf{0 . 3 9}$ \\
& $(0.01)$ & $(0.01)$ \\
Compulsory Voting & 0.31 & 0.31 \\
& $(0.21)$ & $(0.21)$ \\
ENEP & 0.00 & 0.00 \\
& $(0.08)$ & $(0.08)$ \\
Majoritarian & -0.60 & -0.60 \\
& $(0.41)$ & $(0.41)$ \\
Constant & $\mathbf{- 1 . 0 6}$ & $\mathbf{- 1 . 1 6}$ \\
& $(0.39)$ & $(0.39)$ \\
\hline Country Elections & 80 & 80 \\
Observations & 101,899 & 101,899 \\
\hline \hline
\end{tabular}

Note: Multilevel logistic regression with random intercepts at the level of country elections. Standard errors in parentheses. Statistically significant coefficients are boldfaced $(p<0.05)$. Source: CSES

Our first hypothesis is concerned with the impact of polarization: Are voters more likely to turn out when presented with a wide range of choice options? We find that that a party system which is perceived as more polarized makes citizens more likely to vote, in line with hypothesis 1 . At the highest level of polarization, a voter is 13 percentage points more likely to cast a ballot than at the lowest level.

While the overall range of choice options thus seems to be important, citizens are also mobilized by having a party is close to their own position. In line with hypothesis 2, we find that a full-scale increase in the congruence to the closest party makes casting a ballot 15 percentage points more likely. Thus, it becomes clear that respondents very close to a party in terms of their self-placement are significantly more likely to cast a ballot than respondents who 
have a large distance to the closest party. The effects of both polarization and congruence on turnout are shown in Figure 1 below.

Figure 1: Effect of congruence and polarization on turnout
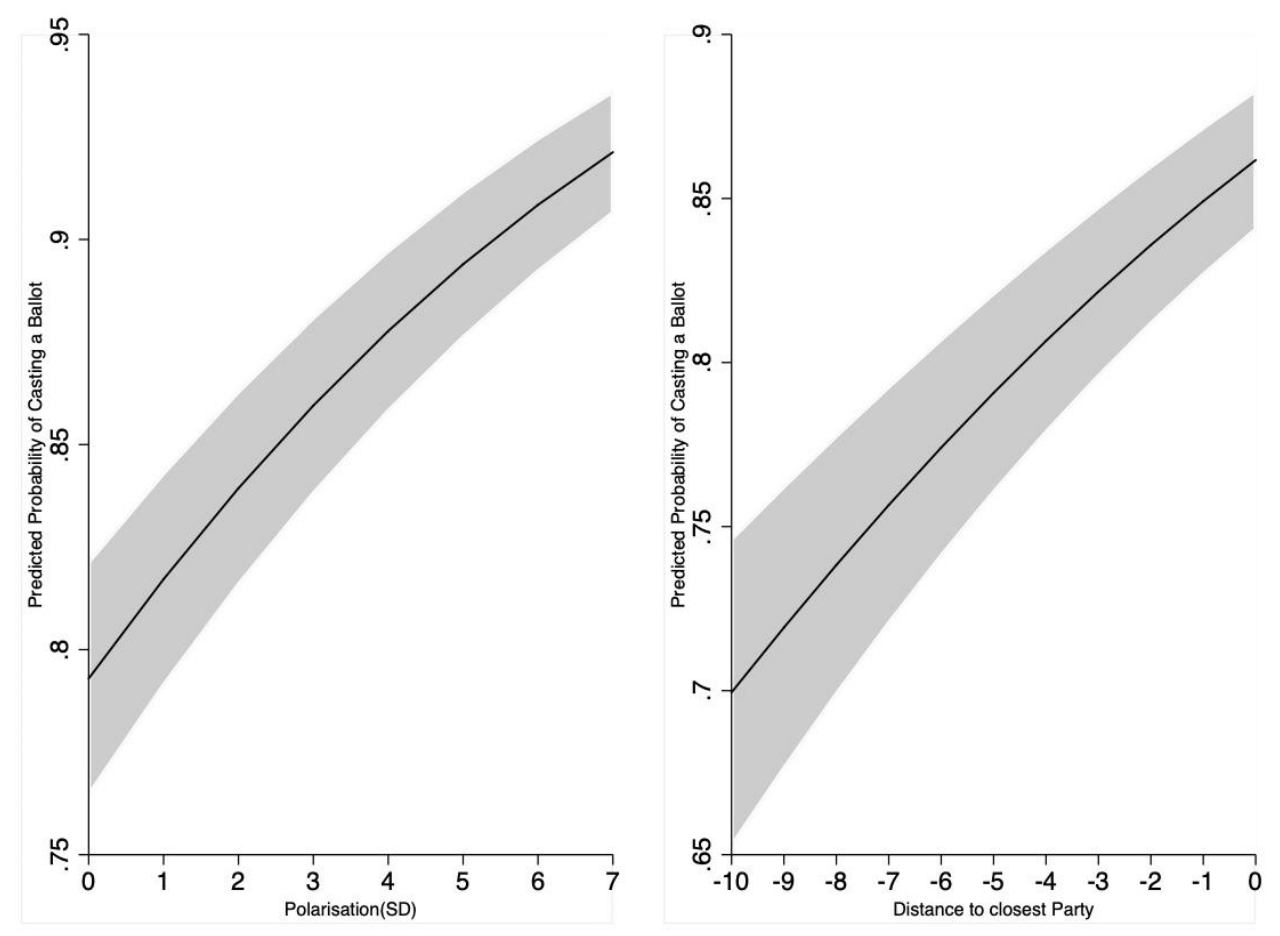

Note: Effect of congruence on the predicted probability of casting a ballot at different levels of polarization.

Based on Model 1 in Table 1 (multilevel logistic regression) with 95\% confidence intervals.

The final part of our analysis is to investigate the impact of congruence at different levels of polarization. We hypothesized that citizens care more about having a party close to their own position when they perceive the party system as highly polarized. In line with Hypothesis 3 we find that the effect of congruence is indeed much stronger if a respondent perceives the party system as highly polarized. At the highest level of polarization, the effect of a one-unit increase in congruence is twice as large compared to the effect at the mean level of polarization (a two per cent increase compared to a one per cent increase). The interaction effect is shown in Figure 2 below. 
Figure 2: Effect of congruence at different levels of polarization

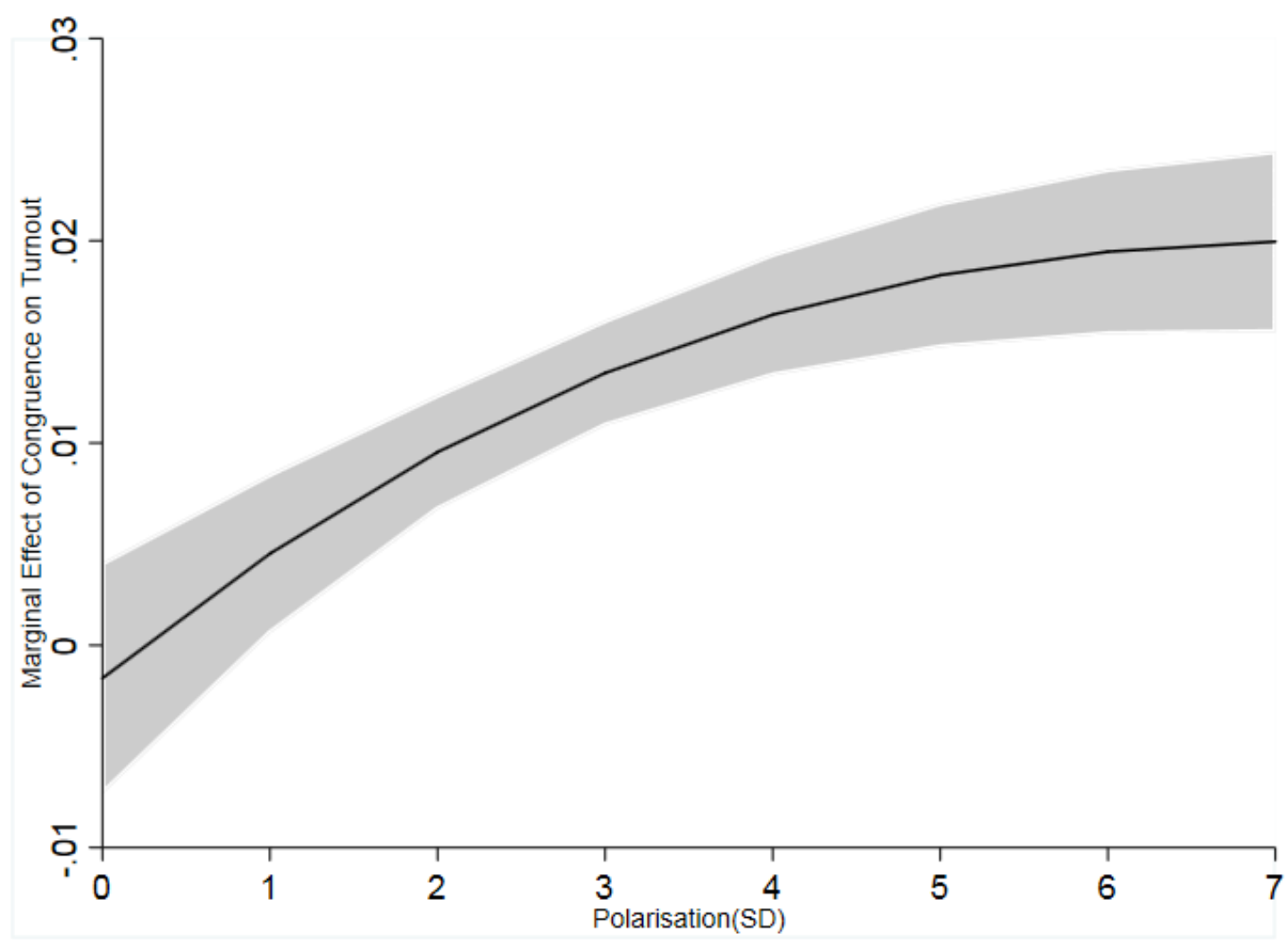

Note: Marginal effect of congruence on the predicted probability of casting a ballot at different levels of polarization. Based on Model 1 in Table 1 (multilevel logistic regression) with 95\% confidence intervals.

Our results for the socio-demographic control variables are in line with findings in the extant literature. We find that older citizens are generally more likely to vote, as are the highly educated and the politically well informed. We also find a small positive effect of being female on the likelihood of voting in some models. At the aggregate level, we surprisingly find no positive effect of any of the electoral system variables, although they are in the expected direction. Importantly, our results also show that the effective number of parties in a political system is not a significant factor in mobilizing citizens. Overall, our analysis thus shows that voters are mobilized by both components of political choice - polarization and congruence. Moreover, voters care more about having a party which is close to them, the more polarized they perceived the party system to be.

While this analysis provides compelling evidence of the effect of political choice on 
turnout, it does not allow us to isolate the effect of changes in the political choice set on voter participation. In the next section, we leverage the emergence of the Alternative für Deutschland (AfD) party and its participation in German regional elections to test the mobilizing effect of the expansion of political choice on citizens across the political spectrum.

\section{The Rise of the Alternative for Germany}

The emergence of a new party in a previously unoccupied ideological position is a rather rare phenomenon in established democracies. However, such an occurrence represents a strong test for our argument that ideological polarization and congruence are important motivating factors for citizens to cast a ballot. Conveniently, the rise of AfD party provides us with the opportunity for such a test. In the light of the experience of the National Socialist dictatorship, far-right positions have for a long time been discredited in Germany, preventing the rise of a successful party on the far right of the political spectrum. Citizens with a far-right ideology in Germany have thus only had the option to vote for a party with a very different ideological platform or to abstain, or to vote for a radical right-wing party such as the NPD or Die Republikaner, which rarely had a realistic change of crossing the five per cent threshold.

This situation changed with the emergence of the AfD. Originally founded in opposition to Germany's involvement in Eurozone bailouts in 2013, the party became quickly successful in German federal, European and state elections ${ }^{5}$, seizing the electoral space on the right of the political spectrum (Arzheimer, 2015: 552).The support of moderate activists free from the stigma of racism and Neo-Nazism is an important condition for the success of new radical right parties according to Art (2011), and the initial dominance of disaffected moderate conservatives in the party's leadership has arguably contributed to its initial success in the German context in contrast to former new parties on the right (Arzheimer, 2015, p. 540). The party incrementally moved further to the right after a change of leadership and increasingly ran on a xenophobic platform, a change mirrored in its electorate (Schmitt-Beck, 2017: 144). Nevertheless, there is still a relatively broad spectrum of right-wing ideology within the party, with explicitly authoritarian and nationalist positions seemingly more dominant in the Eastern Laender 
(Jankowski et al., 2017, p. 714).

To measure the impact of an expanded political choice-set, we exploit the participation of the AfD in the German regional elections. Since the federal elections 2013, the AfD has stood in all regional elections (Landtagswahlen). These elections are scattered throughout the electoral calendar with different Länder constitutions providing for different term lengths, and thus after its formation the AfD would simply field candidates in each upcoming regional election. This case thus presents us with a unique opportunity to study the effect of the emergence of a new right-wing challenger party on turnout in general and on the propensity of right-wing voters in particular. With the timing of the elections being determined exogenously by the electoral calendar, rather than strategically by the party itself, we are in a position to compare turnout within several Länder before and after the AfD became available as a choice option. We are specifically interested in two questions here: First, did the likelihood of voting increase for all citizens, given the wider choice set (increased polarization) after the 'treatment'? Second, did the likelihood of casting a ballot increase particularly for voters on the extreme right of the political spectrum, given the emergence of a party which is close to them (congruence)?

To examine the impact of the presence of the AfD on turnout, we rely on the Landtagswahlen dataset of the German Longitudinal Election Study (GLES). For the dataset, preelection surveys were conducted for all Landtagswahlen since 2010. Overall, we analyze 13 election studies for the time period from 2010 to 2016 (see the Supplemental Information Section C Table SI4). In order to keep other sources of variation constant, we only focus on Länder for which we have election results from before and after the AfD decided to run and use Land fixedeffects. As our independent variable, we use vote intention on a five-point-scale ranging from 1 (very unlikely to cast a ballot) to 5 (very likely to cast a ballot). We group respondents according to their self-placement on an 11-point scale as left (1-4), centrist (5-7) and right (8-11). In addition, we control for a number of socio-demographic variables such as age, gender, income and education and include a dummy for whether the country is an East or West German state. Descriptive statistics can be found in the Supplemental Information (Section B, Table SI3). The results of the regression analysis are shown in Table 2. 
Table 2: The effect of AfD candidates on turnout

\begin{tabular}{|c|c|c|}
\hline & Model 1 & Model 2 \\
\hline AfD & $\begin{array}{c}\mathbf{0 . 1 1} \\
(0.03)\end{array}$ & $\begin{array}{c}\mathbf{0 . 1 1} \\
(0.04)\end{array}$ \\
\hline Left & $\begin{array}{c}\mathbf{0 . 0 8} \\
(0.03)\end{array}$ & $\begin{array}{c}\mathbf{0 . 1 1} \\
(0.04)\end{array}$ \\
\hline Right & $\begin{array}{l}-0.03 \\
(0.03)\end{array}$ & $\begin{array}{l}-0.06 \\
(0.03)\end{array}$ \\
\hline AfD x Left & & $\begin{array}{l}-0.06 \\
(0.04)\end{array}$ \\
\hline AfD x Right & & $\begin{array}{c}\mathbf{0 . 1 1} \\
(0.05)\end{array}$ \\
\hline Age & $\begin{array}{c}\mathbf{0 . 0 1} \\
(0.00)\end{array}$ & $\begin{array}{c}\mathbf{0 . 0 1} \\
(0.00)\end{array}$ \\
\hline Gender & $\begin{array}{l}-0.03 \\
(0.02)\end{array}$ & $\begin{array}{l}-0.03 \\
(0.02)\end{array}$ \\
\hline Income & $\begin{array}{c}\mathbf{0 . 0 4} \\
(0.01)\end{array}$ & $\begin{array}{c}\mathbf{0 . 0 4} \\
(0.01)\end{array}$ \\
\hline Education & $\begin{array}{c}\mathbf{0 . 0 7} \\
(0.01)\end{array}$ & $\begin{array}{c}\mathbf{0 . 0 7} \\
(0.01)\end{array}$ \\
\hline East & $\begin{array}{c}-0.14 \\
(0.07)\end{array}$ & $\begin{array}{c}-0.14 \\
(0.07)\end{array}$ \\
\hline Land FE & $\checkmark$ & $\checkmark$ \\
\hline Constant & $\begin{array}{c}\mathbf{4 . 0 3} \\
(0.10)\end{array}$ & $\begin{array}{c}\mathbf{4 . 0 3} \\
(0.10)\end{array}$ \\
\hline Observations & 5743 & 5743 \\
\hline
\end{tabular}

Note: OLS regression with fixed effects at the level of Länder (omitted). Standard errors in parentheses. Statistically significant coefficients are boldfaced $(p<0.05)$.

We the run an OLS regression with fixed effects at the Land level and fit two models: Model 1 with the main effect and Model 2 in which we interact a dummy for the presence of the AfD with the ideological categories. We also include clustered standard errors at the election level. An overview of the Land elections included in the analysis can be found in the supplemental information (Section C, Table SI4).

As for the results, the coefficient for the AfD dummy is significant, indicating that there is an overall mobilizing effect of the presence of this party in the party system due to higher polarization. When the AfD is present, voters are around 2.5 per cent more likely to cast a ballot compared to the previous election in the same Land without the AfD (see Figure 3). 
Figure 3: Mobilization effect of the AfD

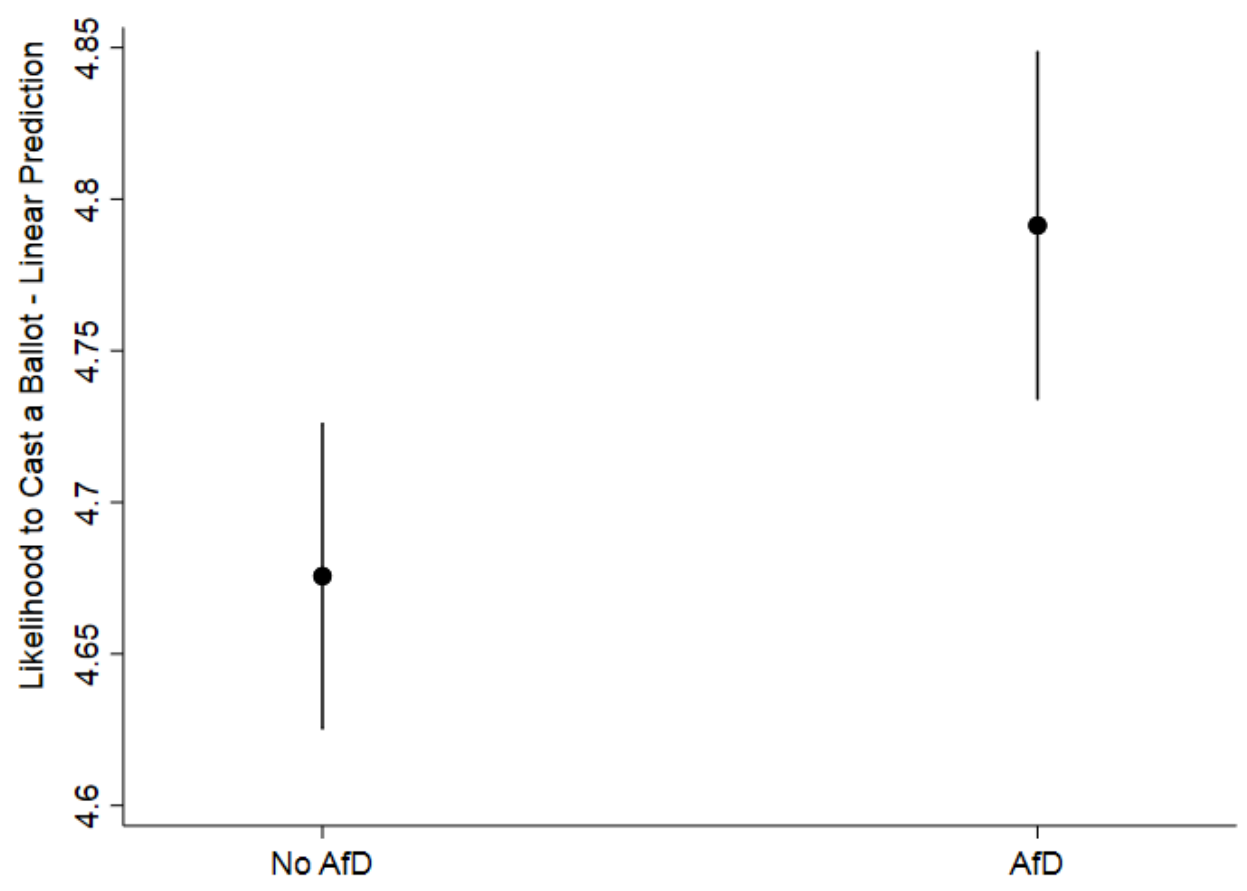

Note: Effect of the presence of the AfD on the likelihood of casting a ballot (linear prediction). Based on Model 1 in Table 2 (OLS fixed effects regression with 95\% confidence intervals).

Next, we analyze the effect of mobilization by the AfD for different groups of voters. The interaction term is significant for voters placing themselves on the right of the political spectrum, indicating that this group is significantly more likely to be mobilized by the AfD compared to the baseline category, centrist voters. Figure 4 clearly shows these different levels of by the AfD. 
Figure 4: Mobilization effect of the AfD by ideology

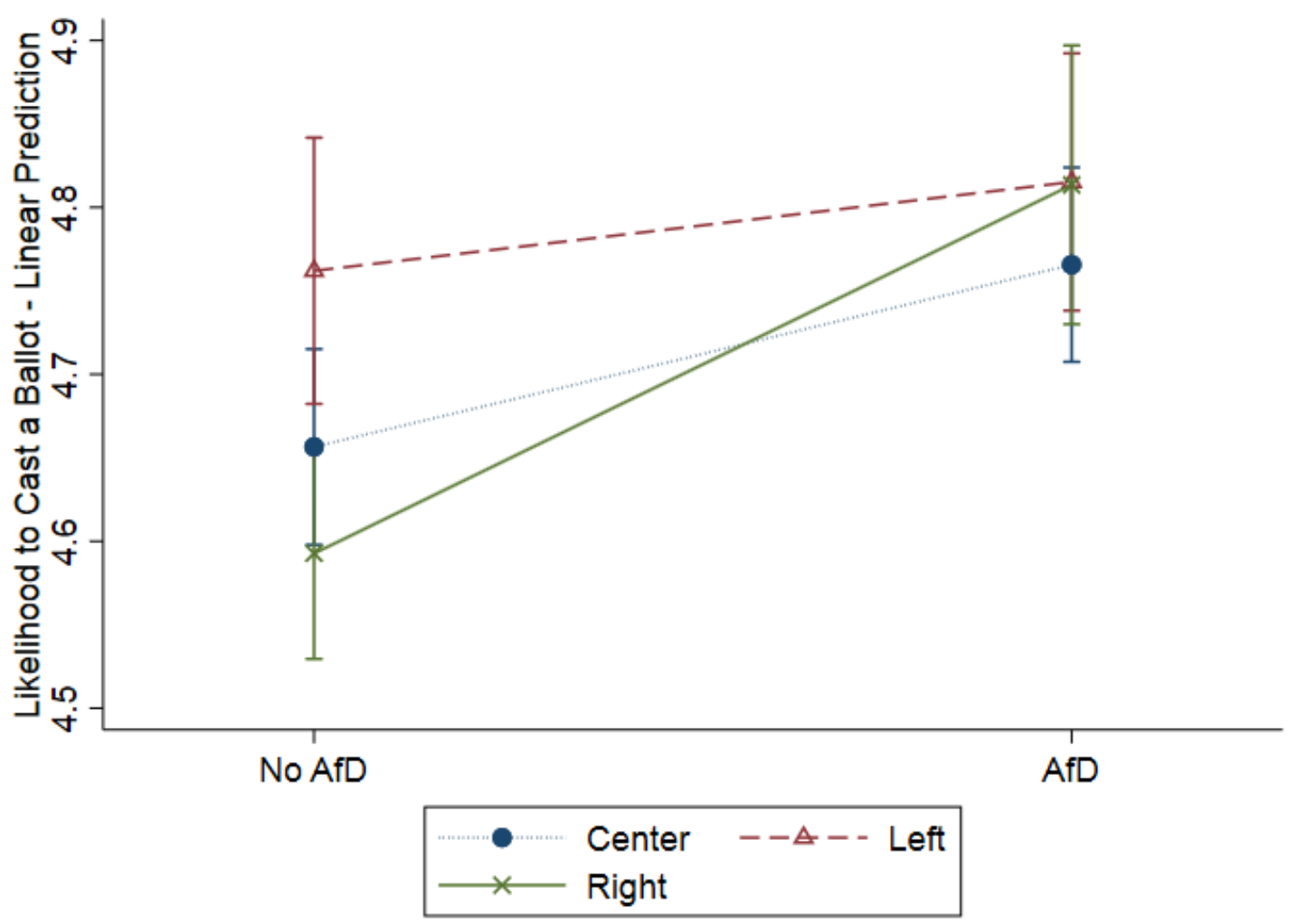

Note: Effect of the presence of the AfD on the likelihood of casting a ballot, by ideological self-placement (linear prediction). Based on Model 2 in Table 2 (OLS fixed effects regression with 95\% confidence intervals).

The mobilization effect is strongest for right-wing voters, with an increase in the likelihood of casting a ballot of 4.5 percentage points, compared to a 2.4 percentage point increase for centrist voters. It is interesting to note that even for left-wing voters the likelihood of casting a ballot increases by around 1.1 percent. Before the entrance of the AfD, right-wing voters were the least likely group to cast a ballot, while in its presence they are the most likely to vote. ${ }^{6}$ As further evidence for the impact of the AfD standing as a congruent choice option on the propensity to vote for right-wing voters, we plot predictive margins for vote intention of

\footnotetext{
${ }^{6}$ A problem associated with electoral survey research in general and pre-election surveys in particular is overreporting of turnout (Silver, Anderson and Abramson, 1986). One particular problem is a survey effect, in which participation in the survey raises the respondents' attention and motivates them to vote, overestimating actual turnout (Clarijs et al., 2007). However, Calrijs et al. find in an experimental study that this effect is only significant for left-wing voters, and that turnout for this group might be overstated, while they find a negative effect for right wing voters. Thus, turnout among left-wing voters tends to be exaggerated while turnout for right-wing voters tends to be underestimated (ibid.). In fact, our estimation might thus be conservative and the mobilizing effect of congruence on right-wing voters might actually be higher. Moreover, the actual results of the elections in which the AfD stood seem to confirm our findings.
} 
right-wing voters. Figure 5 shows that there is a clear increase in the propensity to cast a ballot among people who identify as right-wing since the AfD stood for the first time in September 2013. ${ }^{7}$

\section{Figure 5: Likelihood of casting a ballot among right-wing voters in regional elections}

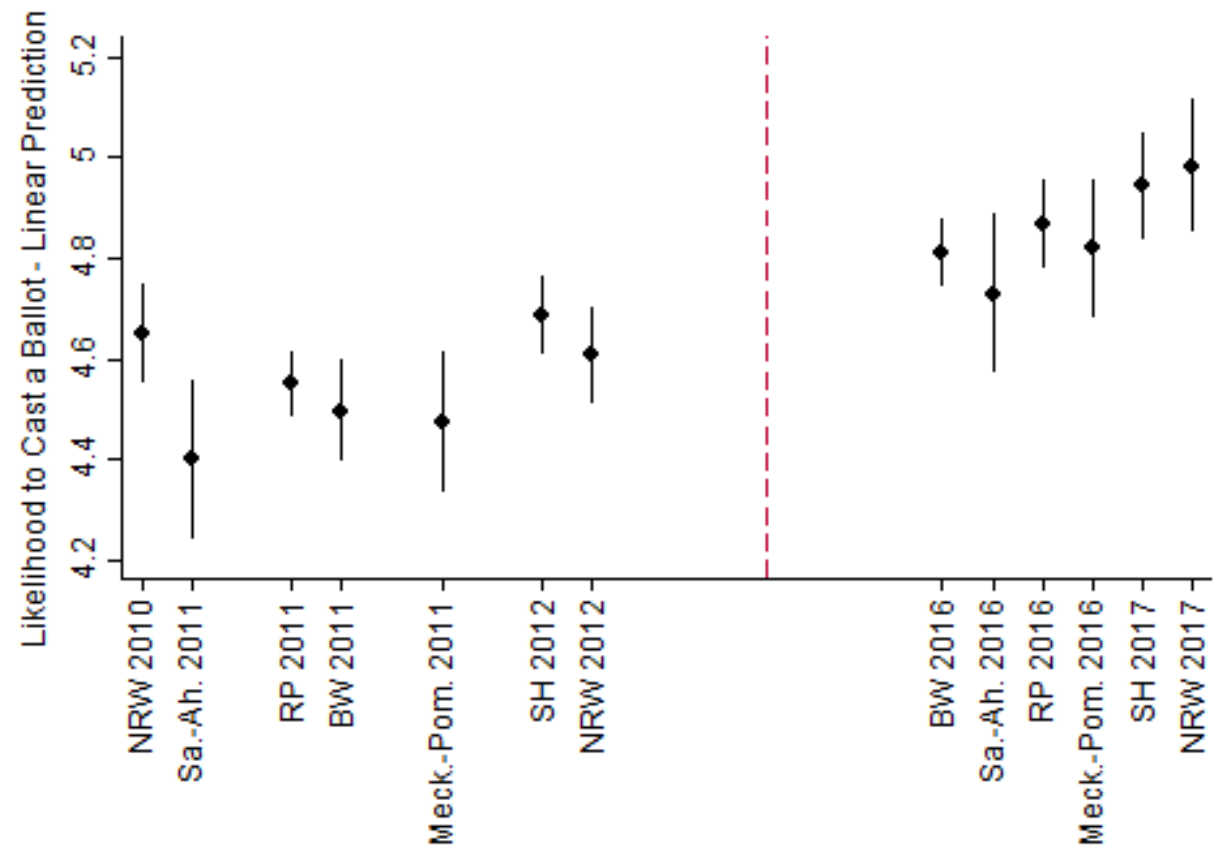

Note: Average likelihood of casting a ballot for right-wing voters in different regional elections in (linear prediction). The dashed line indicates the entrance of the AfD into the party system. Based on Model 2 in Table 2 (OLS fixed effects regression with $95 \%$ confidence intervals).

These findings provide further evidence to support the conclusions based on our observational analysis. Both polarization and congruence have a positive effect on people's likelihood to vote. First, there appears to be a mobilizing effect of ideological polarization, since even centrists and even left-wing voters are more motivated to vote when a new right-wing party is present and the party system is consequently more polarized. Second, we find a strong and significant effect of congruence. With the rise of the AfD, right-wing voters finally have a

\footnotetext{
7 One potential criticism of our approach is that the rise of the AfD coincided with the height of the refugee and migrant crisis in Germany, when over one million people sought asylum in the country over the course of 2015 without the AfD being available as an electoral choice option, a comparable mobilization of right-wing voters by way of the refugee issue would not have been possible, since all other major parties supported the line of Chancellor Merkel to some extent (Engler et al., 2018, p. 15). Thus, while the AfD may have benefited from public concerns about Angela Merkel's refugee policy, its presence as a new choice option in the German political system was arguably a necessary condition for this highly politicized topic to become a factor in electoral politics.
} 
choice option which is close to their own position (but not so radical as to be socially unacceptable). ${ }^{8}$ We thus find that the likelihood to vote is much higher when the AfD stood compared to when the AfD did not run. This effect is significantly stronger than the effect of polarization for the other groups of voters. The effect becomes clearly visible when we plot the predicted values for the vote intention of right-wing voters over time. As a robustness check for our results, we use nearest-neighbor matching for right-wing voters who had the AfD available as a choice option and those who did not. The matching approach confirms our results from the regression analysis, as discussed below (Supplemental Information, Section J Table SI11).

\section{Robustness Checks}

We devise a number of strategies to address various points concerning the robustness of our results. The regression tables can be found in the Supplemental Information (SI) to this paper. First, we check whether our results concerning polarization are sensitive to the specific operationalization of polarization (the standard deviation of party placements) that we have used by testing two alternative measures. The literature has identified various measures of party system polarization (e.g. Dalton, 2008; Ezrow, 2008). Those can vary quite significantly depending on the distribution of parties in the political space, so it is prudent to test the robustness of our results using different operationalizations. While the standard deviation captures the dispersion around the mean party position in the system, the range gives us an idea of the distance between the extremes in the party system. When we operationalize polarization as the range between the most left-wing and most right-wing party a respondent places, we find the same direct effect of polarization on turnout as for the standard deviation, as shown in the Supplemental Information (SI Section D, Table SI5). Moreover, we run an analysis using fragmentation of the party system (the effective number of parliamentary parties)

\footnotetext{
${ }^{8}$ Data on voter migration at the aggregate level based on exit polls reveal that while the AfD gained a significant number of votes from former voters of left-wing parties as well, the by far largest share came from the centre-right parties CDU/CSU and AfD in the 2013 federal elections and the 2014 European Parliament elections (in which the AfD gained 500, 000 votes from the CDU/CSU and only roughly half of that number from the SPD and Die Linke combined. In the Eastern Länder, the AfD also gained significantly from Die Linke but this party has a different electoral base in the East as the successor of the former ruling party of the GDR (Hildebrandt, 2015, p. 33). Most importantly, the AfD has gained significantly among former non-voters. More information on voter migration to the AfD can be found in the appendix.
} 
instead of polarization. We do not find a significant effect for effective number of parliamentary parties (ENEP). The interaction of ENEP and congruence is also not significant, whereas the main effect for congruence remains significant. This indicates that voters value a broad ideological range of choices, and not just a high number of parties (SI Section E, Table SI6). These results indicate that our measure of polarization was well chosen and indeed captures the property of the party system we are most interested in.

Second, we take various steps to account for potential institutional differences between the various countries and over time that may drive turnout differences. We control for key institutional differences in all of our main models, such compulsory voting, effective number of parties and type of electoral system. We also run our models with fixed effects and the estimates are substantially similar to those of our main models (SI Section F, Table SI7).

Third, we account for potential confounding factors at the individual-level. A concern may be that it is in fact political sophistication which drives the effects of congruence and polarization on turnout, e.g. because political sophisticated respondents are both better able to place a high number of parties on an ideological scale and more likely to vote. While we control for political sophistication in all models, we take a further step by running a split-sample model with only the most sophisticated respondents. The effects for congruence, polarization and their interaction remain practically identical using just this sub-sample. (SI Section G, Table SI8). Furthermore, we run the analysis excluding voters who have a perceived polarization of zero, as well as the few voters who are further than 5 points removed from their closest party. Our aim is to check that our findings are not driven by such outliers. However, the results stay substantially similar when excluding those observations (SI Section H, Table SI9). We also control for the popularity of the leader party the individual likes the most (SI Section I, Table SI10). The purpose of this robustness check is to examine whether the perception of party leaders' popularity and competence (i.e. valence issues) renders the effect of congruence and polarization insignificant. While, as expected, the most liked leader's popularity is highly significant and positive in the model, the coefficients for congruence, polarization and their interaction remain significant as well, further highlighting the robustness of our findings and the fact that ideological congruence and polarization play an important role in turnout decisions. Moreover, we control for whether a respondent reports feeling attached to a 'close party' (SI Section J, Table SI11). This dummy for partisanship has a significant and substantially 
large effect, showing that respondents who report having a 'close party' are more likely to turn out. However, the effects for polarization, spatial congruence and their interaction remain significant under this specification, lending our spatial measure of congruence further credibility. Finally, a potential concern with election studies is that that turnout is over reported for reasons of social desirability (e.g. Hill and Hurley, 1984, Selb and Munzert, 2013). We thus use the political weight included in the CSES dataset which corrects for actual turnout (SI Section K, Table SI12). The results stay robust under this specification.

As a robustness check for our analysis of the rise of the Alternative for Germany, we use nearest-neighbor matching among right-wing voters from both the treatment and control groups. This approach allows us to compare respondents in a Land in which the AfD ran with respondents in a Land in which the AfD did not run, but which are otherwise very similar on all other independent variables (e.g. Sekhon 2009). This method has frequently been used to estimate the impact of exogenous interventions on turnout (e.g. Kousser and Mullin 2007). We find that also when matching the respondents on age, sex education and income, the respondents in the treatment group (i.e. where the AfD stands) are significantly more likely to cast a ballot (SI Section L, Table SI13). Overall, these additional analyses give us confidence in the robustness of our findings.

\section{Conclusion}

Competition between different political parties is traditionally seen at the distinguishing feature of democracy compared to other forms of government. Political choice is thus at the core of many assessments of the quality of democratic systems. However, we know less about how different properties of political choice shape individual decisions to participate in elections: Are citizens mobilized by the availability of a wide range of choice? Are turnout decisions determined by whether voters have one party that is close to their own political position? And, does ideological proximity matter more in highly polarized systems?

While there is a vast literature on turnout, this paper contributes to the understanding of how political choice shapes individual-level turnout decisions in three distinct ways. Firstly, we adopt an individual-level perspective to better explain how the main properties of the 
political choice set - polarization and congruence - shape turnout decisions. We argue that citizens will care about not only the differences between the parties on offer, but also on the availability of an offer that closely matches individual preferences. While the lack of ideological polarization can lead to abstention due to indifference, the lack of a congruent choice can lead to abstention due to alienation. Second, we do not treat the effect of these choice components as independent of one another, but argue that in systems perceived to be more polarized it will matter more to citizens' turnout decisions whether or not they have a congruent choice. Finally, we use an innovative strategy to test these arguments empirically, combining a cross-national multi-level analysis of individual turnout in 80 legislative elections in 27 countries using CSES data with a study the mobilizing effect of the rise of the AfD in Germany. The former provides large-N comparative data on the importance of choice for turnout, while the latter study gives us a better handle on the causal effect of change in the choice set on turnout.

Both sets of empirical analyses lend support to our propositions: individuals are more likely to turn out when parties are seen to offer more choice and when they can find a party with matching positions. The paper thus addresses the debate between those arguing that polarization has a mobilizing effect and those arguing that it has a demobilizing effect, by showing that it is not only polarization, but also congruence that matters. In other words, a system such as the US political system may be highly polarized, but offer limited congruent choice to voters in the center, and may thus have a demobilizing effect on those voters in the center who do not have a congruent choice. In contrast, the expansion of choice in Germany on the right of the political spectrum with the emergence of the AfD has led to an increase in turnout, especially among those voters who hold right-wing views. Moreover, our study demonstrates that in systems with high levels of polarization, congruent choice has a stronger mobilizing effect than in systems where parties are more similar.

This also speaks to the wider debate on what determines turnout. Much has been written to address the puzzle of why voters turnout despite the minimal chance of influencing election outcome. While the findings in paper cannot solve this paradox of voting, it does contribute to our understanding of when and why some voters are more likely to turn out. The implications of this paper is that we should take the context more seriously when we consider models of voting behavior: our findings suggest that citizens consider the entire choice set, and not just the characteristics of individual parties (e.g. the incumbent) when making choices, and that 
ideological proximity thus matters more in systems that generally offer more choice. Further research could explore how differences in experiences with varying political choice sets may shape how choices influence behavior. Our findings also have implications beyond the literature turnout, as they confirm the mobilizing effect of greater, and more congruent, political choice in multiparty systems in Europe. This speaks to the possible positive implications of the rise challenger parties both on the left and the right in Europe. The findings here suggest that part of the secret of their success may be that such parties are able to mobilize previous nonvoters, who felt that parties were too similar and did not represent their views.

\section{Acknowledgements}

The research for this paper was generously supported by the European Research Council (ERC GA 647835, EUDEMOS). We are also grateful to the Tarik Abou-Chadi, Jim Adams, Chris Anderson, Sebastian Barfort, Oli Proksch, Toni Rodon, Chris Wratil and the anonymous reviewers for their valuable comments on previous versions of our paper.

\section{Supporting Information}

Additional Supporting Information may be found in the online version of this article at the publisher's website. 


\section{References}

Art, David 2011. Inside the Radical Right. The Development of Anti-Immigrant Parties in Western Europe. Cambridge: Cambridge University Press.

Abramowitz, Alan. 2010. The disappearing center: Engaged citizens, polarization, and American democracy. Yale University Press.

Adams, James, Michael Clark, Lawrence Ezrow and Garrett Glasgow. 2006. “Are niche parties fundamentally different from mainstream parties? The causes and the electoral consequences of Western European parties' policy shifts, 1976-1998." American Journal of Political Science 50(3):513-529.

Adams, James and Samuel Merrill. 2003. "Voter turnout and candidate strategies in American elections." The Journal of Politics 65(1):161-189.

Arzheimer, Kai (2015). “The AFD: Finally a successful right-wing populist eurosceptic party for germany?" West European Politics, 38(3), 535-556.

Bartolini, Stefano. 1999. "Collusion, competition and democracy: Part I." Journal of theoretical politics 11(4):435-470.

Blais, André. 2000. To vote or not to vote?: The merits and limits of rational choice theory. University of Pittsburgh Press.

Blais, André and Agnieszka Dobrzynska. 1998. “Turnout in electoral democracies.”

European Journal of Political Research 33(2):239-261.

Blais, André and Daniel Rubenson. 2013. “The source of turnout decline: New values or new contexts?" Comparative Political Studies 46(1):95-117.

Brennan, Geoffrey and Alan Hamlin. 1998. "Expressive voting and electoral equilibrium." Public Choice 95(1-2):149-175.

Brockington, David. 2009. "It's About The Benefits: Choice Environments, Ideological Proximity and Individual Participation in 28 Democracies." Party Politics 15(4):435-454. 
Brody, Richard A and Benjamin I Page. 1973. "Indifference, alientation and rational decisions." Public Choice 15(1):1-17.

Clarijs, Peter, Bas Hogeling, Philip Hans Franses and Christiaan Heij. 2007. Evaluation of survey effects in pre-election polls. Technical Report EI 2007-50 Erasmus University Rotterdam, Erasmus School of Economics (ESE), Econometric Institute.

Crepaz, Markus ML. 1990. “The impact of party polarization and postmaterialism on voter turnout." European Journal of Political Research 18(2):183-205.

Dahl, Robert A. 1956. A preface to democratic theory. Vol. 115 University of Chicago Press.

Dahl, Robert Alan. 1971. Polyarchy: Participation and Opposition. Yale University Press.

Dalton, Russell J. 1985. "Political parties and political representation: Party supporters and party elites in nine nations." Comparative Political Studies 18(3):267-299.

Dalton, Russell J. 2008. “The quantity and the quality of party systems: Party system polarization, its measurement, and its consequences." Comparative Political Studies 41(7):899_ 920.

Dorussen, Han and Kyriaki Nanou. 2006. “European integration, intergovernmental bargaining, and convergence of party programmes." European Union Politics 7(2):235-256.

Downs, Anthony. 1957. An Economic Theory of Democracy. New York: Harper

Enelow, James M and Melvin J Hinich. 1984. The spatial theory of voting: An introduction. Cambridge University Press.

Engler, F., Bauer-Blaschkowski, S., and Zohlnhöfer, R. (2018). Disregarding the Voters? Electoral Competition and the Merkel Government's Public Policies, 2013-17. German Politics, 1-20.

Evans, Geoffrey and James Tilley. 2017. The new politics of class: the political exclusion of the British working class. Oxford University Press.

Evans, Geoffrey and Nan Dirk De Graaf. 2013. Political choice matters: explaining the strength of class and religious cleavages in cross-national perspective. Oxford University Press.

Ezrow, Lawrence. 2008. “Parties' policy programmes and the dog that didn't bark: No evidence 
that proportional systems promote extreme party positioning." British Journal of Political Science 38(3):479-497.

Feddersen, Timothy J. 2004. "Rational choice theory and the paradox of not voting." Journal of Economic perspectives 18.1: 99-112.

Fiorina, Morris. 1990. "Information and Rationality in Elections." In Information and Democratic Processes, eds. John Ferejohn and James Kuklinski. Urbana: University of Illinois Press, pp.329-42.

Fiorina, Morris P, Samuel A Abrams and Jeremy C Pope. 2008. "Polarization in the American public: Misconceptions and misreadings." The Journal of Politics 70(2):556-560.

Fiorina, Morris P, Samuel J Abrams and Jeremy Pope. 2006. Culture war?: The myth of a polarized America. Longman Publishing Group.

Franklin, Mark N. 2004. Voter turnout and the dynamics of electoral competition in established democracies since 1945. Cambridge University Press.

Geys, Benny. 2006. "Rational theories of voter turnout: a review." Political Studies Review 4.1: $16-35$

Green, Jane and Sara B Hobolt. 2008. “Owning the issue agenda: Party strategies and vote choices in British elections." Electoral Studies 27(3):460-476.

Hamlin, Alan and Colin Jennings. 2011. “Expressive political behaviour: Foundations, scope and implications." British Journal of Political Science 41(3):645-670.

Harding, Robin. 2011. “Freedom to Choose and Democracy: The Empirical Question." Economics \& Philosophy 27(3):221-245.

Hetherington, Marc J. 2008. Turned off or turned on? The effects of polarization on political participation, engagement, and representation. In Red and blue nation. Brookings Institution Press.

Hildebrandt, C. (2015). The Left Party in Germany. New Politics,15(2), 31-36. Retrieved from https://search.proquest.com/docview/1655358230?accountid=9630 
Hill, Kim Quaile and Hurley Particia A. (1984). Nonvoters in voters' clothing: The impact of voting behavior misreporting on voting behavior research. Social Science Quarterly, 65(1), 199.

Jankowski, M., Schneider, S., \& Tepe, M. (2017). Ideological alternative? Analyzing Alternative für Deutschland candidates' ideal points via black box scaling. Party Politics, 23(6), 704-716.

Kittilson, Miki Caul and Christopher J Anderson. 2011. Electoral Supply and Voter Turnout. In Citizens, Context and Choice, ed. Russel Dalton and Christopher J Anderson. Oxford: Oxford University Press pp. 33-54.

Krosnick, Jon A. 1990. “Americans' perceptions of presidential candidates: A test of the projection hypothesis." Journal of Social Issues 46(2):159-182.

Lefkofridi, Zoe, Nathalie Giger and Aina Gallego. 2014. “Electoral participation in pursuit of policy representation: ideological congruence and voter turnout." Journal of Elections, Public Opinion and Parties 24(3):291-311.

Lindberg, Staffan I. 2006. “The surprising significance of African elections." Journal of Democracy 17(1):139-151.

Mair, Peter. 2008. Political Parties and Party Systems. In Europeanization: New Research Agendas, ed. Paolo Graziano and Maarten P. Vink. London: Palgrave Macmillan pp. 154-166.

McDonald, Michael and Ian Budge. 2005. Elections, Parties, and Democracy: Conferring the Median Mandate. Oxford University Press.

Peress, Michael. 2011. "Securing the base: electoral competition under variable turnout." Public Choice 148(1-2):87-104.

Pitkin, Hanna F. 1967. The concept of representation. University of California Press.

Powell Jr, G. Bingham. 1980. "Voting turnout in thirty democracies: Partisan, legal, and socioeconomic influences." Electoral participation: A comparative analysis 534.

Powell, G Bingham. 1982. Contemporary Democracies: Participation, Stability, and Violence. Harvard University Press.

Przeworski, Adam. 2003. "Freedom to choose and democracy." Economics $\mathcal{E}$ 
Philosophy19(2):265-279.

Riker, William H., and Peter C. Ordeshook. 1968. "A Theory of the Calculus of Voting." American Political Science Review 62.1: 25-42.

Rodon, Toni. 2017. “When the kingmaker stays home: Revisiting the ideological bias on turnout." Party Politics 23(2):148-159.

Rogowski, Jon C. 2014. “Electoral choice, ideological conflict, and political participation.” American Journal of Political Science 58(2):479-494.

Rosenstone, Steven J and John Hansen. 1993. Mobilization, participation, and democracy in America. Macmillan Publishing.

Rotemberg, Julio J. 2009. "Attitude-dependent altruism, turnout and voting." Public Choice 140(1-2):223-244.

Sartori, G. 1976. Parties and Party Systems. A Framework for Analysis. Vol. 1. Cambridge University Press.

Schattschneider, Elmer E. 1942. Party Government: American Government in Action. Farrar and Rinehart.

Schmitt-Beck, Rüdiger. 2017. “The Alternative für Deutschland in the electorate: between single-issue and right-wing populist party." German politics 26(1):124-148.

Selb, Peter and Munzert, Simon (2013). Voter overrepresentation, vote misreporting, and turnout bias in postelection surveys. Electoral Studies, 32(1), 186-196.

Siaroff, Alan and John W A Merer. 2002. "Parliamentary Election Turnout in Europe since 1990." Political Studies 50(5):916-927.

Silver, Brian D., Barbara A. Anderson and Paul R. Abramson. 1986. “Who Overreports Voting?” The American Political Science Review 80(2):613-624.

Stevenson, Randolph T and Raymond Duch. 2013. "The meaning and use of subjective perceptions in studies of economic voting." Electoral Studies 32(2):305-320. 
Weisberg, Herbert F and Bernard Grofman. 1981. "Candidate evaluations and turnout." American Politics Quarterly 9(2):197-219. 